\title{
New Complexes of Co(II) With Benzilbis (semicarbazone) \& Amino Acids
}

\section{Zuhoor F. Dawood College of Education Mosul University} Received
07/02/2007

\author{
Rawa D. Sulman
}

Accepted

17/07/2007

\begin{abstract}
الخلاصة
تم تحضير معقدات جديدة للكوبلت (II) مع مزيج من ليكاندي بنزل بس (سميكاربازون)-

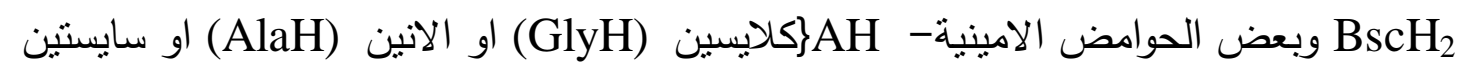

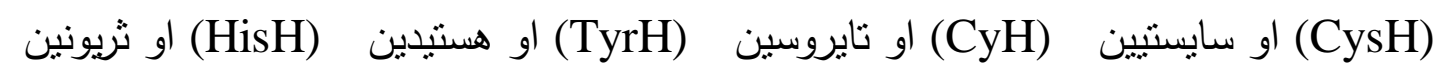
(ThrH) واو برولين (ProH) وتتخيصها بالطرق الفيزيائية و الكيميائية. وجد ان الصيغ البنائية العامة للمعقدات هي :

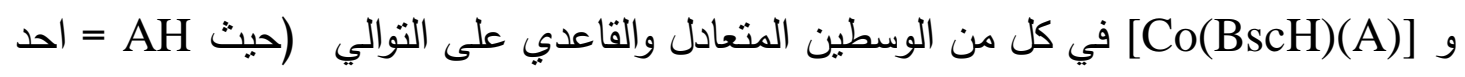

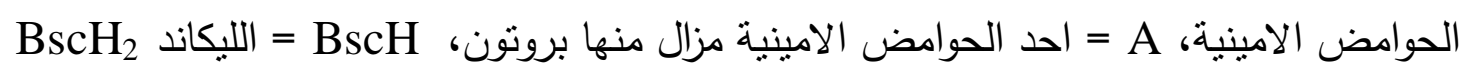

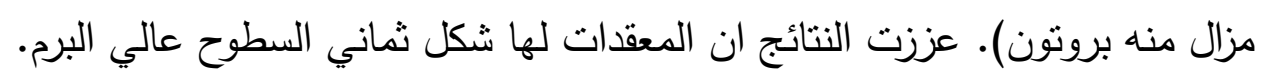

\begin{abstract}
New cobalt (II) complexes with mixed ligands including benzilbis(semi- carbazone)- $\mathrm{BscH}_{2}$ and amino acids- $\mathrm{AH}$ \{glycine (GlyH) or alanine $(\mathrm{AlaH})$ or cysteine $(\mathrm{CysH})$ or cystine $(\mathrm{CyH})$ or tyrosine $(\mathrm{TyrH})$ or histidine $(\mathrm{HisH})$ or threonine $(\mathrm{ThrH})$ or proline $(\mathrm{ProH})\}$ have been prepared and characterized physiccochemically. They have been found to have general formulas $\left[\mathrm{Co}\left(\mathrm{BscH}_{2}\right)(\mathrm{AH})\left(\mathrm{NO}_{3}\right)\right]\left(\mathrm{NO}_{3}\right)$ or $\left[\mathrm{Co}\left(\mathrm{BscH}_{2}\right)(\mathrm{AH})\right]\left(\mathrm{NO}_{3}\right)_{2}$ and $[\mathrm{Co}(\mathrm{BscH})(\mathrm{A})]$ in neutral and basic medium, respectively (where $\mathrm{AH}=$ any of the amino acid, $\mathrm{A}=$ deprotonated amino acid, $\mathrm{BscH}=$ deprotonated $\mathrm{BscH}_{2}$ ligand). The results supported that the complexes had high spin octahedral geometries.
\end{abstract}

\section{INTRODUCTION}

A good deal of work had been reported on the synthesis and characterization of semicarbazones and their complexes [1-4] due to their capability of acting as multidentate donor with the formation of either mono- or bi- or poly-nuclear complexes [5,6]. In addition, semicarbazones and their complexes had important biological activities $[7,8]$ and providing models for metal ligand bonding sites in several enzymes [9].Amino acids complexes with transition metal ions played an important 
role in biochemistry and biology. Great attention had been paid to elucidate and interprete the structural characteristics and the thermodynamic of these biologically ligand complexes [10-14]. The more common coordination of amino acids was as bidentate chelate through the $\mathrm{N}$ and $\mathrm{O}$ atoms which gave rise to a thermodynamically stable five-membered ring for $\alpha$-amino acids (six-membered ring for $\beta$-amino acids). GlyH, AlaH, TyrH and ProH acted as bidentate chelating ligands. Wheras HisH and $\mathrm{ThrH}$ were acted as either tridentate or bidentate chelating ligands. $\mathrm{CysH}$ was a major metal binding site in proteins. It was ambidentate in that it could be tridentate or bidentate through combination of $(\mathrm{S}, \mathrm{N}),(\mathrm{N}, \mathrm{O})$ or $(\mathrm{S}, \mathrm{O})$ donor sets. The ligand $\mathrm{CyH}$ chelated through $(\mathrm{N}, \mathrm{O})$ donor atoms with first row transition elements [15].

There has been growing interest in the formation of mixed ligand complexes of transition and non transition metals [16-20] due to their importance in the field of metalloenzymes and other biological activities $[21,22]$.

Due to the biological importance of mixed ligand complexes, we took a modest part in the coordination chemistry of mixed ligand complexes and some articles have been published on their coordination chemistry with transition and non-transition metal ions [23-27].

In the present work, new cobalt (II) complexes with mixed ligand benzilbis(semicarbazone) and amino acids (Figure1) have been synthesized and characterized physicochemically.

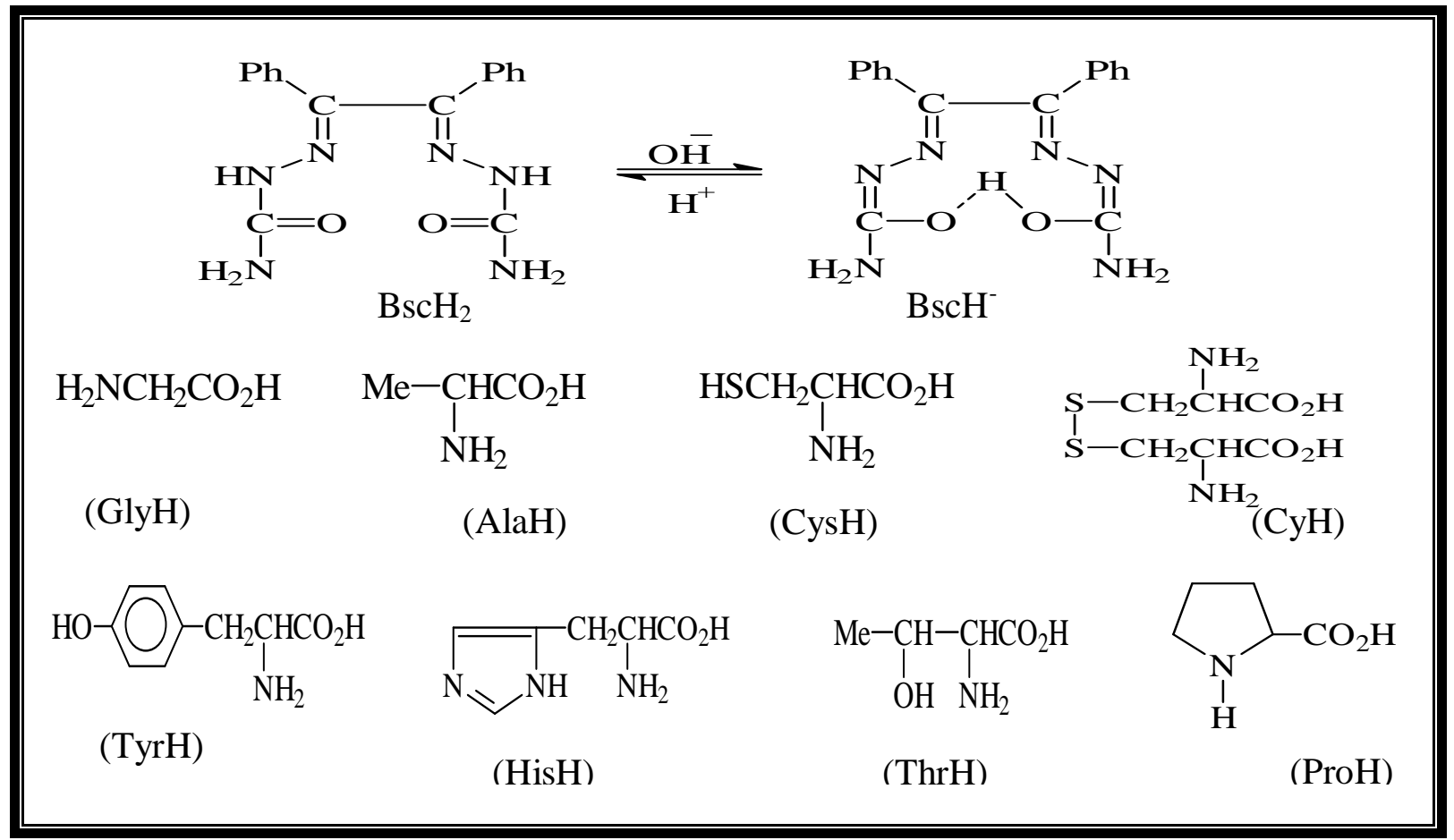

Figure 1: Structures of the ligands

EXPERIMENTAL 


\section{Starting Materials}

The chemicals: cobalt (II) nitrate, benzil, semicarbazide hydrochloride, dimethylformamide, potassium hydroxide, petroleum ether (b.p $=60-80{ }^{\circ} \mathrm{C}$ ), glycine, alanine, cysteine, cystine, tyrosine, histidine, threonine and proline (BDH or Fluka) were used as supplied.

\section{Synthetic Methods}

Benzilbis(semicarbzone)- $\mathrm{BscH}_{2}$ has been prepared according to the published method [28].

Complexes of the type $\left[\mathrm{Co}\left(\mathrm{BscH}_{2}\right)(\mathrm{AH})\right]\left(\mathrm{NO}_{3}\right)_{2}$ and $\left[\mathrm{Co}\left(\mathrm{BscH}_{2}\right)(\mathrm{AH})\left(\mathrm{NO}_{3}\right)\right] \mathrm{NO}_{3}$ have been prepared by the reaction of aqueous solution of cobalt nitrate $(0.50 \mathrm{~g}, 0.0017$ mole $)$ with hot aqueous solution of amino acid ( 0.0017 mole, the amounts in grams were listed in Table 1) and hot ethanolic solution of $(0.56 \mathrm{~g}, 0.0017$ mole $)$ benzilbis(semicarbazone) in 1:1:1 molar ratio. The mixture has been refluxed for three hours followed by evaporation to about half its volume then cooled. The precipitate was filtered off, washed with cold petroleum ether and dried.

Complexes of the type $[\mathrm{Co}(\mathrm{BscH})(\mathrm{A})]$ have been prepared by the reaction of aqueous solution of cobalt nitrate with hot aqueous solution of amino acid and hot ethanolic solution of benzilbis(semicarbazone) in 1:1:1 molar ratio. Potassium hydroxide solution $(1 \mathrm{M})$ has been added until $\mathrm{pH}$ of the solution has been adjusted to get complete precipitation (Table 1). The mixture has been heated on a water bath for few minutes then cooled. The product was filtered off, washed with petroleum ether and dried.

\section{Analytical and Physical Measurements}

Cobalt contents have been determined by applying precipitation method [29] after the decomposition of the complexes with concentrated nitric acid. Relative molecular weights of the complexes have been determined cryoscopically [30].

Molar conductivities of the complexes have been measured in an electrolytic conductivity measuring set LF-42 using $10^{-3} \mathrm{M}$ dimethylformamide solutions at room temperature. The infrared spectra has been recorded on FT-IR Bruker type Tensor 27 in the range 400-4000 $\mathrm{cm}^{-1}$ using $\mathrm{KBr}$ pellets. Electronic spectra has been recorded by Shimadzu UV-1601 Spectrophotometer for $10^{-3}$ or $10^{-4} \mathrm{M}$ solution of the ligand and their complexes in dimethylformamide at $25{ }^{\circ} \mathrm{C}$. Magnetic susceptibilities of the complexes have been measured by Bruker B.M6.

\section{RESULTS AND DISCUSSION}

The reaction of cobalt (II) nitrate with benzilbis(semicarbazone) and amino acids in both neutral and basic medium can be represented by the following reactions:

$\mathrm{Co}\left(\mathrm{NO}_{3}\right)_{2} \cdot 6 \mathrm{H}_{2} \mathrm{O}+\mathrm{AH}+\mathrm{BscH}_{2} \longrightarrow\left[\mathrm{Co}\left(\mathrm{BscH}_{2}\right)(\mathrm{AH})\right]\left(\mathrm{NO}_{3}\right)_{2}+6 \mathrm{H}_{2} \mathrm{O}$ 
$\mathrm{Co}\left(\mathrm{NO}_{3}\right)_{2} \cdot 6 \mathrm{H}_{2} \mathrm{O}+\mathrm{AH}+\mathrm{BscH} \mathrm{H}_{2} \longrightarrow\left[\mathrm{Co}\left(\mathrm{BscH}_{2}\right)(\mathrm{AH})\left(\mathrm{NO}_{3}\right)\right]\left(\mathrm{NO}_{3}\right)+6 \mathrm{H}_{2} \mathrm{O}$

$\mathrm{Co}\left(\mathrm{NO}_{3}\right)_{2} \cdot 6 \mathrm{H}_{2} \mathrm{O}+\mathrm{AH}+\mathrm{BscH}_{2}+2 \mathrm{KOH} \longrightarrow[\mathrm{Co}(\mathrm{BscH})(\mathrm{A})]+2 \mathrm{KNO}_{3}+8 \mathrm{H}_{2} \mathrm{O}$

(where $\mathrm{A}=$ deprotonated amino acid, $\mathrm{BscH}=$ deprotonated $\mathrm{BscH}_{2}$ )

The resulted complexes were colored solid, soluble in dimethylformamide and dimethylsulfoxide. Cobalt contents and the relative molecular weight revealed that the complexes had the composition $\left[\mathrm{Co}\left(\mathrm{BscH}_{2}\right)(\mathrm{AH})\right]\left(\mathrm{NO}_{3}\right)_{2}, \quad\left[\mathrm{Co}\left(\mathrm{BscH}_{2}\right)(\mathrm{AH})\left(\mathrm{NO}_{3}\right)\right] \mathrm{NO}_{3}$ and $[\mathrm{Co}(\mathrm{BscH})(\mathrm{A})]$ in neutral and basic medium respectively (Table 1). The molar conductivities values $\left(110-152,43-58,1.25-19 \Omega^{-1} \cdot \mathrm{cm}^{2} \cdot \mathrm{mol}^{-1}\right)$ approached those expected for 1:2, 1:1 and non electrolytes of the complexes prepared in neutral and basic medium, respectively [31]. The room temperature magnetic moments of cobalt (II) complexes were in the range 3.31-3.99 B.M (Table 2) suggesting the presence of three unpaired electrons [26] The low magnetic moments of Co (II) complexes compared to the expected values for six-coordinate high-spin octahedral compexes possibly attributed to the ligand participation and may be due to transfer of electron from cobalt ion to the ligand and hence the complexes were spin free with octahedral geometry [32-34].

The most important infrared spectral bands that provided conclusive structural evidence for the coordination of the ligands to the central metal ions were given in Table3. The infrared spectra of semicarbazone ligand showed a strong band at $1579.55 \mathrm{~cm}^{-1}$ attributed to $\mathrm{C}=\mathrm{N}$ group was shifted towards a lower frequency region on coordination due to the decrease of the bond order as a result of metal nitrogen bond formation $[7,35,36]$. The other band at $1684.73 \mathrm{~cm}^{-1}$ assigned to $\mathrm{C}=\mathrm{O}$ group $[35,36]$ was shifted towards a lower frequency on coordination for complexes $1,3,5,7,9,11,13$ and 15 indicating the coordination of carbonyl oxygen to the metal ion [26,36] in neutral medium. Meanwhile, in basic medium, this band was disappeared in the complexes 2,4,6,8,10,12,14 and 16 and a new band was observed at $1213.35-1225.28 \mathrm{~cm}^{-1}$ due to C-O group, thereby establishing the coordination of the ligand through the enolic oxygen atom $[26,27,36]$. The other observed band at $3221.26 \mathrm{~cm}^{-1}$ due to $\mathrm{NH}$ group remained unaltered in the complexes prepared in neutral medium indicating that there is no coordination through the $\mathrm{NH}$ group $[7,25,36]$. Whereas, in basic medium due to the presence of hydrogen bonding it is more difficult to notice the absence of $\mathrm{NH}$ group, but it is well known that this band was disappeared in basic medium due to the enolic form. The other strong bands at 3473.95 and $1447.12 \mathrm{~cm}^{-1}$ assigned to $v_{\mathrm{NH} 2}$ and $\delta_{\mathrm{NH}_{2}}$ remained unaltered in all the complexes indicating that there is no coordination through this group [7,26].

As regards chelation through amino acids, the infrared spectra exhibited significant features in the $v_{\mathrm{NH}_{2}}$ and $v_{\mathrm{COO}}$ regions. It is worthwhile to mention here that the free amino acids existed as zwitter 
ions and the infrared spectra of these could not be compared entirely with those of metal complexes as amino acids in the complexes did not exist as zwitter ions. Free amino acids showed $\mathrm{vNH}^{3}{ }^{+}$in the range of 3130-3030 $\mathrm{cm}^{-1}$. In the complexes, $\mathrm{NH}_{3}{ }^{+}$is deprotonated and bound to the metal ion through the neutral $\mathrm{NH}_{2}$ group [18]. The transformation of $\mathrm{NH}_{3}{ }^{+}$to $\mathrm{NH}_{2}$ must be resulted in an upward shift in $\mathrm{v}_{\mathrm{NH} 2}$. At the isoelectric point the free amino acids showed $v_{\mathrm{NH} 2}$ in the region 3300.00-3500.00 $\mathrm{cm}^{-1}$ $[11,15,18]$. On complexation the infrared spectra showed characteristic bands in the region $3246.00-3150.00 \mathrm{~cm}^{-1}$, which were lower compared to those of free $v_{\mathrm{NH}_{2}}$ indicating that the nitrogen of the amino group was involved in coordination. The amino group involvement in the coordination was supported by the presence of two well-resolved bands at 3335.00 and $3278.00 \mathrm{~cm}^{-1}$ for cobalt (II) complexes [15]. The infrared spectra showed a strong evidence in support of the involvement of carboxylate group in coordination. In comparison with the free amino acids, the $v_{\text {as }}\left(\mathrm{COO}^{-}\right)$showed positive shifts and $v_{\mathrm{s}}\left(\mathrm{COO}^{-}\right)$recorded negative shifts, which confirmed the monodenticity $[18,35,36]$ of the carboxylate group. The vibrational frequencies related to $v_{\text {as }}\left(\mathrm{COO}^{-}\right)$and $v_{\mathrm{s}}\left(\mathrm{COO}^{-}\right)$occurred at $1332.21-1417.84 \mathrm{~cm}^{-1}$ and $1590.63-1635.38 \mathrm{~cm}^{-1}$ while for cobalt complexes they were observed at 1348.64-1458.44 and $1500.00-1638.46 \mathrm{~cm}^{-1}$, respectively $\left(\Delta v=151.36-180.02 \mathrm{~cm}^{-1}\right)$ and these values were an indication that only one oxygen atom of $\mathrm{COO}^{-}$group was involved in coordination to the metal ion. Thus, it might be concluded that amino acids acted as monobasic bidentate in these complexes coordinating through amino nitrogen and carboxylate oxygen $[15,18]$.

In addition to the above observations, complexes numbers 3,5,7 and 9 showed bands at 1417.47-1446.09, 1284.41-1302.50 and 1025.34$1026.15 \mathrm{~cm}^{-1}$ due to $v_{\mathrm{s}}\left(\mathrm{NO}_{3}\right), v_{\text {as }}\left(\mathrm{NO}_{3}\right)$ and $v$ (NO), respectively. The presence of these bands suggested that the nitrate ion joint to the metal ion as monodentate ligand [36].

The spectra of the complexes $1,3,5,7,9,11,13$ and 15 showed new bands at $1370.54-1390.00 \mathrm{~cm}^{-1}$ due to the ionic nature of nitrate groups [34]. In addition new bands were observed in the spectra of all the complexes at $691.31-702.58 \mathrm{~cm}^{-1}$ and $525.86-551.63 \mathrm{~cm}^{-1}$ due to $v_{\mathrm{Co}-\mathrm{N}}$ and $v_{\text {Co-O }}$, respectively[37]. The presence of these bands (Table 3) supported the coordination of the ligands to the metal ion[7,18,26].

The ultraviolet spectra of amino acids showed bands at 39992.00$49751.24 \mathrm{~cm}^{-1}$ and $37919.00-38510.41 \mathrm{~cm}^{-1}$ due to $\pi-\pi^{*}$ and $\mathrm{n}-\pi *$ electronic transitions. The shift of these absorption bands on complexation (38150.00-47555.20 and 35560.00-36550.54 $\mathrm{cm}^{-1}$ ) indicated the participation of the ligand molecules in complex formation $[24,26]$. 
The ultraviolet spectra of the $\mathrm{BscH}_{2}$ ligand showed bands at 40779.70-47569.21 $\mathrm{cm}^{-1}$ and 37698.86-38510.41 $\mathrm{cm}^{-1}$ due to the electronic transitions $\pi-\pi^{*}$ and $\mathrm{n}-\pi^{*}$. The shift of these absorption bands (40000.00-46500.00 and 36650.00-37500.00 $\left.\mathrm{cm}^{-1}\right)$ on complexation indicated the participation of the ligand molecules in the complex formation $[26,27]$.

In the visible region, cobalt (II) complexes showed two absorption bands at $15000.00-16042.50 \mathrm{~cm}^{-1}$ and $17064.84-20161.29 \mathrm{~cm}^{-1}$ due to the electronic transitions ${ }^{4} \mathrm{~T}_{1} \mathrm{~g}(\mathrm{~F}) \rightarrow{ }^{4} \mathrm{~A}_{2} \mathrm{~g}(\mathrm{~F})-v_{2}$ and ${ }^{4} \mathrm{~T}_{1} \mathrm{~g}(\mathrm{~F}) \rightarrow{ }^{4} \mathrm{~T}_{1} \mathrm{~g}(\mathrm{P})-v_{3}$ expected for $\mathrm{d}^{7}$ system in octahedral field [38]. $v_{1}$ (attributed to the electronic transition ${ }^{4} \mathrm{~T}_{1} \mathrm{~g}(\mathrm{~F}) \rightarrow{ }^{4} \mathrm{~T}_{2} \mathrm{~g}(\mathrm{~F})$ ) has been not observed due to instrumental limitation, it is calculated by the literature method [38]. The ligand field parameter $\mathrm{B}$ and the ligand field splitting energy (10 Dq) have been calculated [38].

The values of $\beta$ of the complexes were between $0.81-0.98$ clearly indicate the partial covalent character of the bond concerned. However, the electronic spectral data (Table 4) suggested high spin octahedral geometry for all the complexes [38].

\section{CONCLUSION}

From the above studies, the following observations have been achieved that lead to establish the following points:

1. The ligand $\mathrm{BscH}_{2}$ acted as either tetra or tri-dentate chelating ligand joint to the metal ion through either the two nitrogen and the two oxygen atoms or the two nitrogen and one oxygen atoms.

2. The ligands $\mathrm{AH}$ acted as bidentate chelating ligands joint through the oxygen and nitrogen atoms.

3. Cobalt ion had hexacoordinated resulting in a high spin octahedral geometry.

From the present study we can concluded that the complexes had the following proposed geometries (Figure 2). 

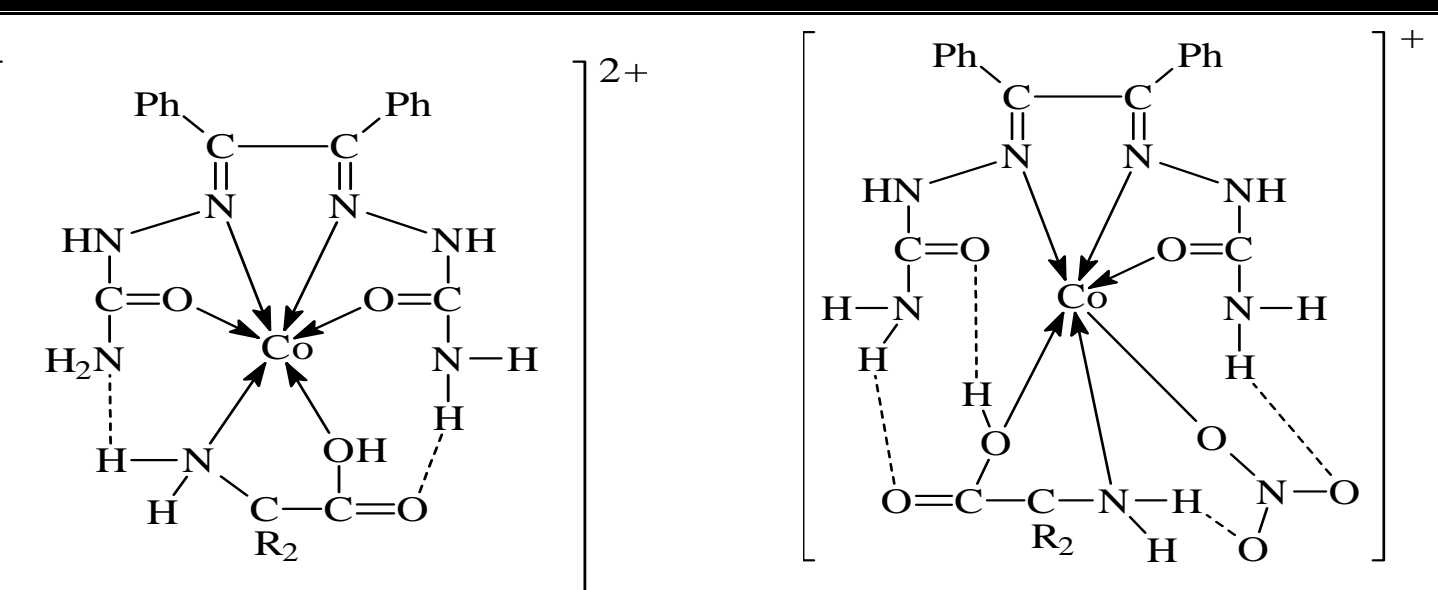

Complexes No. 1. 11. 13. 15

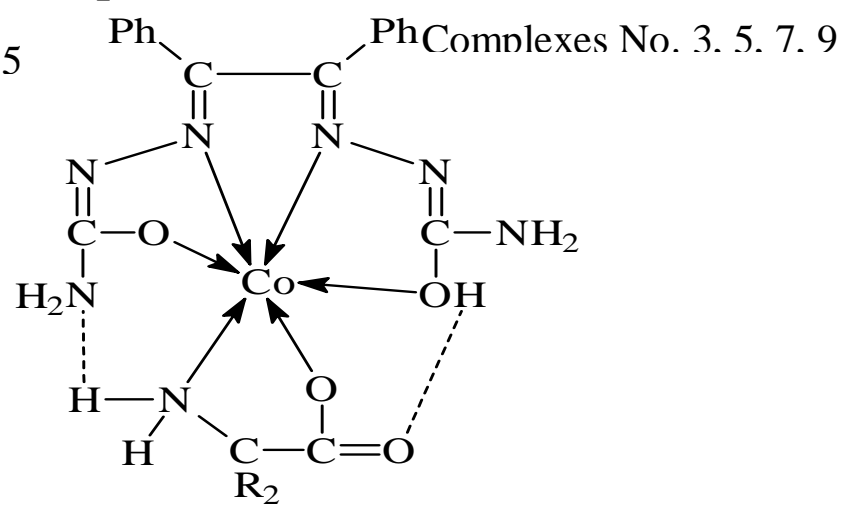

Comnlexes No. 2.4.6.8.10.12.14.16

Figure 2: Structures of the complexes

Table 1: Amounts of amino acids, $\mathrm{pH}$ of the reaction and \% yield of the complexes

\begin{tabular}{|c|c|c|c|c|}
\hline No. & Comp. & $\begin{array}{l}\text { Wt. of amino acid } \\
\text { (gm) }\end{array}$ & pH & \% yield \\
\hline 1 & {$\left[\mathrm{Co}\left(\mathrm{BscH}_{2}\right)(\mathrm{GlyH})\right]\left(\mathrm{NO}_{3}\right)_{2}$} & 0.130 & - & 70.22 \\
\hline 2 & {$\left[\mathrm{Co}\left(\mathrm{BscH}_{2}\right)(\mathrm{Gly})\right]$} & 0.130 & $12-13$ & 82.21 \\
\hline 3 & {$\left[\mathrm{Co}\left(\mathrm{BscH}_{2}\right)(\mathrm{AlaH})\left(\mathrm{NO}_{3}\right)\right] \mathrm{NO}_{3}$} & 0.150 & - & 68.41 \\
\hline 4 & {$[\mathrm{Co}(\mathrm{BscH})(\mathrm{Ala})]$} & 0.150 & $11-12$ & 70.56 \\
\hline 5 & {$\left[\mathrm{Co}\left(\mathrm{BscH}_{2}\right)(\mathrm{CyH})\left(\mathrm{NO}_{3}\right)\right] \mathrm{NO}_{3}$} & 0.210 & - & 69.57 \\
\hline 6 & {$\left[\mathrm{Co}\left(\mathrm{BscH}_{2}\right)(\mathrm{Cy})\right]$} & 0.210 & $10.5-11$ & 70.50 \\
\hline 7 & {$\left[\mathrm{Co}\left(\mathrm{BscH}_{2}\right)(\mathrm{CysH})\left(\mathrm{NO}_{3}\right)\right] \mathrm{NO}_{3}$} & 0.412 & - & 84.36 \\
\hline 8 & {$[\mathrm{Co}(\mathrm{BscH})(\mathrm{Cys})]$} & 0.412 & $11-12$ & 80.44 \\
\hline 9 & {$\left[\mathrm{Co}\left(\mathrm{BscH}_{2}\right)(\mathrm{TyH})\left(\mathrm{NO}_{3}\right)\right] \mathrm{NO}_{3}$} & 0.310 & - & 82.72 \\
\hline 10 & {$[\mathrm{Co}(\mathrm{BscH})(\mathrm{Ty})]$} & 0.310 & $13-14$ & 80.70 \\
\hline 11 & {$\left[\mathrm{Co}\left(\mathrm{BscH}_{2}\right)(\mathrm{HisH})\right]\left(\mathrm{NO}_{3}\right)_{2}$} & 0.270 & - & 71.66 \\
\hline 12 & {$[\mathrm{Co}(\mathrm{BscH})(\mathrm{His})]$} & 0.270 & $13-14$ & 70.68 \\
\hline 13 & {$\left[\mathrm{Co}\left(\mathrm{BscH}_{2}\right)(\mathrm{ThrH})\right]\left(\mathrm{NO}_{3}\right)_{2}$} & 0.204 & - & 82.31 \\
\hline 14 & {$[\mathrm{Co}(\mathrm{BscH})(\mathrm{Thr})]$} & 0.204 & 9.9 & 86.50 \\
\hline 15 & {$\left[\mathrm{Co}\left(\mathrm{BscH}_{2}\right)(\mathrm{ProH})\right]\left(\mathrm{NO}_{3}\right)_{2}$} & 0.197 & - & 72.76 \\
\hline 16 & {$[\mathrm{Co}(\mathrm{BscH})(\mathrm{Pro})]$} & 0.197 & 12.6 & 75.50 \\
\hline
\end{tabular}


Table 2 : Analytical and physical properties of the complexes

\begin{tabular}{|c|c|c|c|c|c|c|}
\hline No. & Color & $\begin{array}{c}\text { M.P } \\
{ }^{\circ} \mathbf{C}\end{array}$ & $\Lambda_{\mathbf{M}}{ }^{*}$ & $\begin{array}{c}\mu_{\text {eff }}{ }^{* *} \\
\text { B.M }\end{array}$ & $\begin{array}{c}\text { Co\% } \\
\text { Calc.(obs.) }\end{array}$ & $\begin{array}{c}\text { M.Wt. } \\
\text { Calc. (obs.) }\end{array}$ \\
\hline 1 & Pale rose & $205-207$ & 110 & 3.65 & $10.12(9.60)$ & $581.90(571.00)$ \\
\hline 2 & Pale brown & 296 & 14.10 & 3.62 & $12.92(12.60)$ & $455.90(445.00)$ \\
\hline 3 & Russet & $201-203$ & 58 & 3.99 & $9.92(9.20)$ & $593.90(585.00)$ \\
\hline 4 & Pale brown & $283-284$ & 6.79 & 3.69 & $12.59(11.80)$ & $467.90(459.00)$ \\
\hline 5 & Dark brown & $>320$ & 52.50 & 3.96 & $9.38(9.20)$ & $627.90(622.30)$ \\
\hline 6 & Pale brown & $238-239$ & 20 & 3.84 & $11.74(11.50)$ & $501.90(499.50)$ \\
\hline 7 & Pale yellow & $228-230$ & 55 & 3.74 & $7.89(8.20)$ & $746.90(740.00)$ \\
\hline 8 & Beige & 243 & 13 & 3.85 & $9.49(9.60)$ & $620.90(615.50)$ \\
\hline 9 & Desert & $214-216$ & 43 & 3.32 & $8.56(8.60)$ & $687.90(680.50)$ \\
\hline 10 & Dark brown & $309-310$ & 19 & 3.81 & $10.48(10.00)$ & $561.90(555.00)$ \\
\hline 11 & Rose & $141-142$ & 125 & 3.77 & $8.90(8.50)$ & $661.90(659.00)$ \\
\hline 12 & Beige & $202-203$ & 13.50 & 3.51 & $10.99(10.80)$ & $535.90(530.00)$ \\
\hline 13 & Pink & 130 & 152 & 3.71 & $9.41(9.30)$ & $625.90(622.00)$ \\
\hline 14 & Brown & 337 & 14 & 3.69 & $11.78(11.40)$ & $499.90(496.00)$ \\
\hline 15 & Purple & 137 & 112 & 3.31 & $9.47(10.00)$ & $621.90(617.50)$ \\
\hline 16 & Brown & 360 & 1.25 & 3.41 & $11.88(11.60)$ & $495.90(490.20)$ \\
\hline
\end{tabular}

$* \Lambda_{\mathrm{M}}:$ Molar conductivities in $\Omega^{-1} \cdot \mathrm{cm}^{2} \cdot \mathrm{mol}^{-1}$

** $\mu_{\text {eff }}$ : Magnetic moment in Bohr Magneton

Table 3 : IR spectra of the complexes (values in $\mathrm{cm}^{-1}$ )

\begin{tabular}{|c|c|c|c|c|c|c|c|c|c|c|c|}
\hline Comp. & $\begin{array}{l}\nu \mathrm{C}=\mathbf{N} \\
\text { semi }\end{array}$ & $\begin{array}{c}v \mathrm{C}=\mathbf{O} \\
\text { semi }\end{array}$ & $\begin{array}{l}v C-O \\
\text { semi }\end{array}$ & $\begin{array}{c}\mathrm{vNH}_{2} \\
\text { A.A }\end{array}$ & $\begin{array}{c}v \mathrm{OH} \\
\text { A.A } \\
\end{array}$ & $\begin{array}{c}v_{(\mathrm{s})} \mathrm{CO}_{2}{ }^{-} \\
\text {A.A. }\end{array}$ & $\begin{array}{c}v_{(\text {(as) }} \mathrm{CO}_{2} \\
\text { A.A. }\end{array}$ & $\Delta v$ & vM-N & vM-O & $\begin{array}{l}\text { Other } \\
\text { bands }\end{array}$ \\
\hline $\mathrm{BsCH}_{2}$ & 1579.55 & 1684.73 & - & & & & & 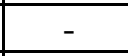 & - & - & - \\
\hline GlyH & - & - & - & 3735.11 & 3649.00 & \begin{tabular}{|l|l|}
1616.27 \\
\end{tabular} & 1132.21 & 284.06 & - & - & \\
\hline AlaH & - & - & - & 3735.16 & 3649.03 & 1593.31 & 1353.03 & 240.19 & - & - & $\begin{array}{c}\mathrm{SH} \\
2361.88\end{array}$ \\
\hline СуH & - & - & - & 3735.35 & 3649.40 & 1610.34 & 1360.89 & 249.45 & - & - & $\begin{array}{c}\square \mathrm{SH} \\
2360.78\end{array}$ \\
\hline CysH & - & - & - & 3798.97 & 3648.97 & 1622.78 & 1406.64 & 216.14 & - & - & \\
\hline TyH & - & - & - & 3735.11 & 3648.98 & \begin{tabular}{|l|l|}
1635.38 \\
\end{tabular} & 1416.49 & 218.89 & - & - & \\
\hline HisH & - & - & - & 3735.11 & 3250.00 & 1590.63 & 1329.63 & 261.00 & - & - & \\
\hline ThrH & - & - & - & 3735.52 & 3648.94 & \begin{tabular}{|l|l}
1624.44 \\
\end{tabular} & 1417.84 & 206.60 & - & - & \\
\hline ProH & - & - & - & 3735.02 & 3648.88 & \begin{tabular}{|l|l|}
1623.39 \\
\end{tabular} & 1377.17 & 246.72 & - & - & \\
\hline 1 & 1530.37 & 1620.36 & - & $\begin{array}{l}3335.00- \\
3278.00\end{array}$ & 3221.26 & 1620.36 & 1462.37 & 157.99 & 699.52 & 525.86 & $\begin{array}{c}v_{\mathrm{NO}_{3}} \\
1384.53\end{array}$ \\
\hline 2 & 1460.88 & - & 1215.45 & $\begin{array}{r}3335.00- \\
3278.00 \\
\end{array}$ & 3300.52 & 1559.06 & 1384.76 & 174.30 & 695.02 & 535.76 & - \\
\hline 3 & 1561.00 & 1663.12 & - & $\begin{array}{c}3335.00- \\
3278.00\end{array}$ & 3300.52 & 1559.06 & 1384.55 & 174.51 & 701.84 & 527.01 & $\begin{array}{c}v_{\mathrm{NO}_{3}} \\
1370.54\end{array}$ \\
\hline 4 & 1541.08 & - & 1215.27 & $\begin{array}{l}3335.00- \\
3278.00 \\
\end{array}$ & 3300.52 & 1500.00 & 1384.57 & 115.43 & 6997.47 & 535.63 & 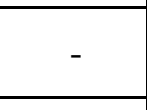 \\
\hline 5 & 1550.00 & 1663.05 & - & $\begin{array}{r}3335.00- \\
3278.00 \\
\end{array}$ & 3392.98 & 1545.54 & 1370.54 & 175.00 & 701.70 & 526.20 & $\begin{array}{c}v_{\mathrm{NO}_{3}} \\
1384.53\end{array}$ \\
\hline 6 & 1541.36 & - & 1216.19 & $\begin{array}{l}3335.00- \\
3278.00 \\
\end{array}$ & 3282.19 & 1550.54 & 1384.38 & 166.16 & 697.27 & 537.08 & - \\
\hline
\end{tabular}




\begin{tabular}{|c|c|c|c|c|c|c|c|c|c|c|c|}
\hline Comp. & $\begin{array}{c}v \mathrm{C}=\mathrm{N} \\
\text { semi }\end{array}$ & $\begin{array}{c}v \mathrm{C}=\mathrm{O} \\
\text { semi }\end{array}$ & $\begin{array}{l}\mathrm{VC}-\mathrm{O} \\
\text { semi }\end{array}$ & $\begin{array}{c}\text { vNH } \\
\text { A.A }\end{array}$ & $\begin{array}{l}\text { vOH } \\
\text { A.A }\end{array}$ & $\begin{array}{l}\mathrm{v}_{(\mathrm{s})} \mathrm{CO}_{2}^{-} \\
\text {A.A. }\end{array}$ & $\begin{array}{c}\mathrm{v}_{(\mathrm{as})} \mathrm{CO}_{2}^{-} \\
\text {A.A. }\end{array}$ & $\Delta v$ & $v \mathbf{M}-\mathbf{N}$ & $v M-O$ & $\begin{array}{l}\text { Other } \\
\text { bands }\end{array}$ \\
\hline 7 & 1559.92 & 1663.64 & - & $\begin{array}{c}3335.00- \\
3278.00\end{array}$ & 3282.19 & 1533.72 & 1318.72 & 165.00 & 698.92 & 527.96 & $\begin{array}{c}v_{\mathrm{NO}_{3}} \\
1384.38\end{array}$ \\
\hline 8 & 1550.68 & - & 1224.21 & \begin{tabular}{|l|}
$3335.00-$ \\
3278.00 \\
\end{tabular} & 3282.19 & 1518.64 & 1348.64 & 167.00 & 692.88 & 550.20 & - \\
\hline 9 & 1561.03 & 1658.49 & - & $\begin{array}{l}3335.00- \\
3278.00\end{array}$ & 3282.19 & 1538.51 & 1370.26 & 168.25 & 702.45 & 527.35 & $\begin{array}{c}v_{\mathrm{NO}_{3}} \\
1385.28\end{array}$ \\
\hline 10 & 1559.61 & - & 1220.25 & \begin{tabular}{|c|}
$3335.00-$ \\
3278.00 \\
\end{tabular} & 3282.19 & 1550.48 & 1384.48 & 166.00 & 695.87 & 535.66 & - \\
\hline 11 & 1560.77 & 1663.41 & - & $\begin{array}{c}3335.00- \\
3278.00\end{array}$ & 3282.19 & 1550.61 & 1384.61 & 166.00 & 702.58 & 526.77 & $\begin{array}{c}v_{\mathrm{NO}_{3}} \\
1390.10\end{array}$ \\
\hline 12 & 1560.87 & - & 1225.18 & \begin{tabular}{|l|}
$3335.00-$ \\
3278.00 \\
\end{tabular} & 3282.19 & 1579.37 & 1404.37 & 178.00 & 691.31 & 551.63 & - \\
\hline 13 & 1547.68 & 1662.42 & - & $\begin{array}{c}3335.00- \\
3278.00\end{array}$ & 3282.19 & 1587.63 & 1407.63 & 180.00 & 698.52 & 526.91 & $\begin{array}{c}v_{\mathrm{NO}_{3}} \\
1384.54\end{array}$ \\
\hline 14 & 1558.76 & - & 1213.35 & \begin{tabular}{|r|}
$3335.00-$ \\
3278.00 \\
\end{tabular} & 3282.19 & 1538.46 & 1458.44 & 180.00 & 697.38 & 536.44 & - \\
\hline 15 & 1550.25 & 1640.33 & - & $\begin{array}{c}3335.00- \\
3278.00\end{array}$ & 3282.19 & 1541.43 & 1375.21 & 166.22 & 699.23 & 550.43 & $\begin{array}{c}v_{\mathrm{NO}_{3}} \\
1384.51\end{array}$ \\
\hline 16 & 1541.09 & - & 1215.06 & \begin{tabular}{|r|}
$3335.00-$ \\
3278.00 \\
\end{tabular} & 3282.19 & 1533.30 & 1458.05 & 175.25 & 697.49 & 535.64 & - \\
\hline
\end{tabular}

Table 4 : Electronic spectral data of the complexes

\begin{tabular}{|c|c|c|c|c|c|c|c|c|c|c|c|c|}
\hline No. & $\begin{array}{c}v_{1}^{*} \\
\mathbf{c m}^{-1}\end{array}$ & $\begin{array}{c}v_{2} \\
\mathrm{~cm}^{-1}\end{array}$ & $\begin{array}{c}v_{3} \\
\mathbf{c m}^{-1}\end{array}$ & $\begin{array}{c}\mathrm{B} \\
\mathrm{cm}^{-1}\end{array}$ & $\begin{array}{l}\text { 10Dq } \\
\mathrm{cm}^{-1}\end{array}$ & $\mathrm{Dq} / \mathbf{B}$ & $v_{3} / \mathbf{B}$ & $v_{2} / v_{1}$ & $v_{3} / v_{1}$ & $v_{3} / v_{2}$ & $\beta$ & $\begin{array}{l}\text { C.T } \\
\text { cm }^{-1}\end{array}$ \\
\hline 1 & 7200.00 & 15400.80 & 17921.14 & 768.49 & 8453.4 & 1.10 & 23.32 & 2.139 & 2.489 & 1.164 & 0.79 & 34722.22 \\
\hline 2 & 7000.00 & \begin{tabular}{|l}
15036.00 \\
\end{tabular} & 18655.00 & 846.03 & 8037.3 & 0.95 & 2.05 & 2.148 & 2.665 & 1.240 & 0.87 & 34013.60 \\
\hline 3 & 7500.00 & 15975.00 & 18518.51 & 794.10 & 8735.1 & 1.10 & 23.32 & 2.130 & 2.469 & 1.159 & 0.82 & 34246.57 \\
\hline 4 & 7050.00 & 15122.25 & 18132.60 & 806.97 & 8069.7 & 1.00 & 22.47 & 2.145 & 2.572 & 1.199 & 0.83 & 34237.19 \\
\hline 5 & 7200.00 & 15408.00 & 18050.54 & 803.32 & 8033.2 & 1.00 & 22.47 & 2.140 & 2.507 & 1.172 & 0.83 & 34482.75 \\
\hline 6 & 7050.00 & 15122.25 & 18132.60 & 806.97 & 8069.7 & 1.00 & 22.47 & 2.145 & 2.572 & 1.199 & 0.83 & 33955.85 \\
\hline 7 & 7300.00 & 15702.30 & 20161.29 & 932.10 & 8388.9 & 0.90 & 21.63 & 2.151 & 2.762 & 1.284 & 0.96 & 34965.03 \\
\hline 8 & 7150.00 & 15229.50 & 17064.84 & 731.77 & 8049.5 & 1.10 & 23.32 & 2.130 & 2.387 & 1.121 & 0.75 & 34136.00 \\
\hline 9 & 7000.00 & 15000.00 & 18200.00 & 852.68 & 7290.3 & 0.85 & 21.22 & 2.130 & 2.580 & 1.210 & 0.88 & 34435.26 \\
\hline 10 & 7050.00 & 15000.00 & 18200.00 & 857.68 & 7290.3 & 0.85 & 21.22 & 2.130 & 2.580 & 1.210 & 0.88 & 34821.36 \\
\hline 11 & 7030.00 & 15200.00 & 18260.00 & 844.20 & 7597.8 & 0.90 & 21.63 & 2.160 & 2.600 & 1.200 & 0.87 & 34321.8 \\
\hline 12 & 7040.00 & 15150.00 & 18650.00 & 896.20 & 7169.6 & 0.80 & 20.81 & 2.150 & 2.650 & 1.230 & 0.92 & 34482.75 \\
\hline 13 & 7150.00 & 15200.00 & 18600.00 & 893.80 & 7150.4 & 0.80 & 20.81 & 2.130 & 2.600 & 1.220 & 0.92 & 34402.09 \\
\hline 14 & 7200.00 & 15408.00 & 18867.92 & 855.69 & 8129.0 & 0.95 & 22.05 & 2.140 & 2.620 & 1.220 & 0.88 & 33783.78 \\
\hline 15 & 7500.00 & 16042.50 & 17985.61 & 771.25 & 8483.8 & 1.10 & 23.32 & 2.134 & 2.400 & 1.120 & 0.80 & 34965.03 \\
\hline 16 & 7100.00 & 15123.00 & 17241.37 & 739.34 & 8132.7 & 1.10 & 23.32 & 2.130 & 2.430 & 1.140 & 0.76 & 34965.03 \\
\hline
\end{tabular}

* calculated 


\section{REFERENCES}

1. P.H. Maurya, B.V. Agarwala and A. Dey, J. Indian Chem. Soc., LV, 418 (1978).

2. H. Schmidhammer, G. Hrovath, M. Riess, C. Ungerank, K. Monory and A. Borsodi, Sci. Pharm., 64, 655 (1996).

3. N.C. Kasuga, K. Sekino, C. Koumo, N. Shimada, M. Ishikawa and K. Nomiya, J. Inorg. Biochem., 84, 55 (2001).

4. D.X.West, I.S. Billeh, J.P. Jasinski, J.M. Jasinski and R.J. Butcher, Transition Met. Chem., 23, 209 (1998).

5. A. Seyam, A. Jarrar and F. Khalili, J. Abhath Al-Yarmouk Basic Sci. and Englo, 2A, 243 (2001).

6. L. Otero, P. Noblia, D. Gambino, H. Cerecetto, M. Gonzalez and R. Sanchez-Delgado, Z. Anorg. Allg. Chem., 629, 1033 (2003).

7. Y. Kumar and S.P. Tolani, Croat. Chem. Acta, 62, 73 (1989).

8. P. Noblia, M. Vieites, B. Parajon Costa, E.J. Baran, H. Cerecetto, P. Draper, M. Gonzalez, O.E. Piro, E.E. Castellano, A. Azqneta, A. Lopez de Carain, A. Monge-Vaga and D. Gambino, J. Inorg. Biochem., 99, 443 (2005).

9. B. Singh, P.L. Manrya and B.V. Agarwala, J. Indian Chem. Soc., 59, 1130 (1982).

10.R.H. Garret and C.M. Grisham, Biochemisty, Saunders, New York (1995).

11.A.M.A. Hassaan, J. Islamic Academy Sci., 4, 271 (1991).

12.S.C. Shoner, A.M. Nienstedt, J.J. Ellison, I.Y. Kung, D. Barnhart and J.A. Kovacs, Inorg. Chem., 37, 5721 (1998).

13.M.C. Caplloneh, A. Garcia-Raso, A. Terron, M.C. Apella, E. Espinosa and E. Molins, J. Inorg. Biochem., 85, 173 (2001).

14.R. Fernandes de Farias, Quim Nova, 25, 729 (2002).

15.A.C. Massabni, P.P. Corbi, P. Melnikov, M.A. Zacharias and H.R. Rechenberg, J. Braz. Chem. Soc., 16 (2005).

16.S.B. Tanaskovic and G. Vuckovic, J. Serb. Chem. Soc., 69, 187 (2004).

17.A.V. Vaidyan and P.K. Bhattacharya, Proc. Inidan Acad. Sci. (Chem. Sci.), 108, 69 (1996).

18.R.R. Reddy and A.M. Reddy, Proc. Indian Acad. Sci. (Chem. Sci.), 112, 593 (2000).

19.M.C.M.M. Fernandes, E.B. Paniago and S. Carvalho, J. Braz. Chem. Soc., 8, 537 (1997).

20.F.S.M. Hassan, Arabian J. Sci. \& Eng., 30, 29 (2005).

21.K.H. Reddy, P.S. Reddy and P.R. Babu, Transition Met. Chem., 25, 505 (2000).

22.R. Ramesh and M. Sivamasundari, Synth. React. Inorg. Met-Org. Chem., 33(5), 899 (2003). 
23.Z.F. Dawood, Sci. \& Tech., 17, 35 (2002).

24.Z.F. Dawood, S.H. Hussein and M.A. Al-Shama'a, Sci. \& Tec. A, 21, 71 (2004).

25.Z.F. Dawood and A.A. Mohammad, J. Edu. Sci., 17, 11 (2005).

26.Z.F. Dawood and M.W. Ibrahim, National J. Chem., 21, 24 (2006).

27.Z.F. Dawood and Y.T. Mahmood, Raf. J. Sci., 17, (4), 1 (2006).

28.A.I. Vogel, Textbook of Practical Organic Chemistry, Longmans Green, London, $3^{\text {rd }}$ ed., 344 (1964).

29.A.I. Vogel, Textbook of Quantitative Inorganic Analysis, Longman Inc., New York, $1^{\text {st }}$ ed., 461 (1981).

30.J.W. Danials, Experimental Physical Chemistry, McGraw-Hill, $6^{\text {th }}$ ed., 81 (1962).

31.W.J. Geary, Coord. Chem. Rev., 7, 81 (1971).

32.G. Wilkinson, R.D. Gillard and J.A. McCleverty, Comprehensive Coordination Chemistry, Pergamon Press, Great Britain, $4^{\text {th }}$ ed.,1184 (1987).

33.R.C. Aggarwal, N.K. Singh and R.P. Singh, J. Indian Chem. Soc., 63, 466 (1986).

34.C.K. Bhaskare and P.G. More, J. Indian Chrm. Soc., 63, 270 (1986).

35.I.J. Bellamy, The Infrared Spectra of Complex Molecules, Chapman and Hall, London, $3^{\text {rd }}$ ed., (1975).

36.K. Nakamoto, Infrared and Raman Spectra of Inorganic and Coordination Compounds, John Wiley and Sons, New York, $3^{\text {rd }}$ ed. (1970).

37.N. Raman, S. Esthar and C. Thangaraja, J. Chem. Sci., 116(4), 209 (2004).

38.A.B.P. Lever, Electronic Spectra of Some Transition Metal Complexes, J. Chem. Educ., 45, 711 (1968). 